Annals of Warsaw University of Life Sciences - SGGW

Land Reclamation No 47 (3), 2015: 211-223

(Ann. Warsaw Univ. of Life Sci. - SGGW, Land Reclam. 47 (3), 2015)

\title{
Estimation of the density state of anthropogenic soils using a dynamic heavy penetrometer (DPH)
}

\author{
WOJCIECH CZACZKOWSKI ${ }^{1}$, EUGENIUSZ KODA ${ }^{2}$, JÜRGEN SCHMID ${ }^{3}$ \\ ${ }^{1}$ AUGENTA Bau Ges.m.b.H. in Vienna \\ ${ }^{2}$ Department of Geotechnical Engineering, Warsaw University of Life Sciences - SGGW \\ ${ }^{3}$ Brambor and Schmid GmbH in Niederkreuzstetten
}

\begin{abstract}
Estimation of the density state of anthropogenic soils using a dynamic heavy penetrometer $(D P H)$. The loading of natural and anthropogenic soils can be determined in the field by using dynamic probing tests. This method is based on the measurement of the resistance, which the studied soil poses on the probe tip when it penetrates the soil. The most typical probe tips are cylindrical, conical and rarely cross-shaped. The penetrometer penetrates the soil by a hammer with a given mass freely falling from the height required in the test. The penetration resistance is defined by the numbers of blows required to drive the penetrometer over the defined distance $\left(N_{k}\right)$, where $k=10$, $15(20)$ or $30 \mathrm{~cm}$. The paper presents the results of heavy dynamic probing tests DPH with a hammer mass of $50 \mathrm{~kg}$ and penetration depth up to $30 \mathrm{~m}$, carried out in an anthropogenic made ground in order to determine the soil loading for the foundation of the designed building.
\end{abstract}

Key words: dynamic probing tests, dynamic heavy penetrometer, density index, anthropogenic soils

\section{INTRODUCTION}

Anthropogenic soils (communal waste, rubble, humus etc.) in urban areas often cause problems with foundation construction. These problems result from the non-uniform grain size in the soils, their variable origin and lack of control of the density state during the construction process. A favorable feature of made soils is usually their susceptibility to densification. When selecting the controlling methods of the density state of made soils, their variable composition, particularly the presence of rock and rubble fragments and solid waste, should be taken into account (Koda 2011, 2012, Pasik et al. 2015).

The density index $\left(I_{D}\right)$ of natural and anthropogenic made soils can be determined in field conditions using dynamic probing tests. This method is based on the measurement of the resistance, which the studied soil poses on the probe tip during soil penetration.

Penetration of the tip into the soil with constant blow energy is provided by a hammer with a specific mass, freely falling from a height required in the test (Herrick and Jones 2002). The conducted attempts allow to obtain the number of blows per unit of probe penetration $(10,15(20)$ or $30 \mathrm{~cm})$.

According to norm ISO 22476-2:2005, five types of dynamic probes are used in dynamic probing tests: light DPL (hammer mass $10 \mathrm{~kg}$ ), medium DPM (hammer mass $30 \mathrm{~kg}$ ), heavy DPH (hammer mass $50 \mathrm{~kg}$ ) and very heavy DPSH-A and DPSH-B (hammer mass $63.5 \mathrm{~kg}$ ).

Dynamic probing is often used in quality control when creating building embankments. Additionally, the test may 
check the density of road foundations (Glinicka 2006), subfloors, subcrusts for pavements, foundations and ramps, as well as road and railway embankments. Density state control in soils is carried out also after conducting dynamic exchange and gravel columns.

The density state of the soil substrate tested with various types of dynamic probes is determined on the basis of empirical formulas from the logarithmic relationship between the density index $\left(I_{D}\right)$ and the number of hammer blows (c). The density state in the analyzed object (Bruckhaufner Hauptstraße 13, 1210 Vienna) was assessed using a dynamic heavy penetrometer (DPH), commonly applied in Austria. The DPH probe has a hammer mass of $50 \mathrm{~kg}$, which allows, depending on the degree of soil density in the studied substrate, a penetration depth of $30 \mathrm{~m}$. Results of dynamic probing tests are commonly interpreted from the critical depth $\left(t_{c}\right)$, which usually is $t_{c}=1.0 \mathrm{~m}$.

The paper presents the results of dynamic probing tests with use of a dynamic heavy penetrometer DPH-50, which were conducted in made soils in order to determine the loading of the soil substrate for the designed building foundation transferring variable load on the substrate (Zadroga 2007).

In the case of a substrate built of anthropogenic soils containing brick, ceramic and concrete rubble, dynamic heavy probing may be an alternative to cone penetration tests (CPT), when large concrete fragments can damage the expensive cones of static probes.

\section{STUDY SITE}

The study object is located in the Bruckhaufen housing society in the Donaufeld area. This area is the southernmost part of the 21 Floridsdorf district of Vienna. The landscape of the area developed in the XVIII century due to the accumulation of the sediments of the non-regulated Danube river.

During regulation works, conducted on the Danube river since 1870 for over 100 years with minor cessations, whose main aim was to provide flood relief of the neighbouring areas, a new channel was dug in the Bruckhaufen stretch, i.e. the New Danube, and an oxbow lake i.e. the Old Danube, separated from the main channel, was formed.

In the substrate the aquifer comprises Quaternary Danube gravels which overlie Tertiary muds and fine-grained deposits.

Since the times of the Austro-Hungarian Empire, the area between the new channel and the oxbow lake was used as a dump for communal waste and rubble. The waste dump was shut down in 1963, after about 80 years of operation. The thickness of the wastes after densifying them with compactors reaches in places $8 \mathrm{~m}$.

Since 1923 , the city authorities have reorganized waste utilization and recycling. A concrete ramp was constructed, from which the delivered wastes were reloaded to carriages of a narrow-gauge railway and distributed around the dump. Waste segregation and recycling was introduced (Licka and Krippner 2011). 
The waste dump capacity is estimated at about $5,000,000 \mathrm{~m}^{3}$, with a mean density at $1.3-1.5 \mathrm{t} / \mathrm{m}^{3}$ and total mass 6,500,000-7,500,000 $\mathrm{t}$ (Lampert et al. 1996).

Presently, the area reclaimed by soil material is allotted as leisure and recreation site by establishing the public park Donaupark with the Donauturm observation tower, and the remaining part is planned for single-family housing of the Bruckhaufen estate.

Within the framework of the EU Project LIFE+ Alte Donau, a network of depression wells was made around the Bruckhaufen-Donaupark waste dump; their role is to decrease the groundwater level and the protection of groundwater against chemical pollutants.

Within the housing estate, in building lots 2220/1 and 2220/2 at Bruckhaufner Hauptstraße 13, 1210 Vienna (Fig. 1), dynamic probing with application of a dynamic heavy penetrometer DPH was conducted to obtain density parameters of anthropogenic soils (wastes) to calculate soil loading for a designed construction of a building at variable load (150 $-585 \mathrm{kN})$, resulting from variable heights of particular parts of the building (Figs 2 and 3).

\section{STUDY METHODS}

Dynamic probing is one of the methods used to determine the density index $\left(I_{D}\right)$ of non-cohesive and anthropogenic soils. This method is based on the measurement of the number of hammer blows during the penetration of the probe tip in the studied soil substrate.

Typically used probes include those with cylindrical (SPT), conical (DPL, DPM, DPH, DPSH) and rarer cross-type (ITB-ZW) tips (Pisarczyk 2012). Penetration of the probe with a constant energy into the soil substrate is achieved by a hammer with a mass relative to the probe type, freely falling from a height determined for particular probes.

The tests supply the number of hammer blows per unit of probe penetration $\left(N_{k}\right)$, where $k=10,15(20)$ or $30 \mathrm{~cm}$.

Experiments have allowed to state that the density state for unsorted sands with a uniformity coefficient at $C_{U} \leq$ $\leq 6$ (Patakiewicz and Zabielska-Adamska 2013) can be determined from the relation-
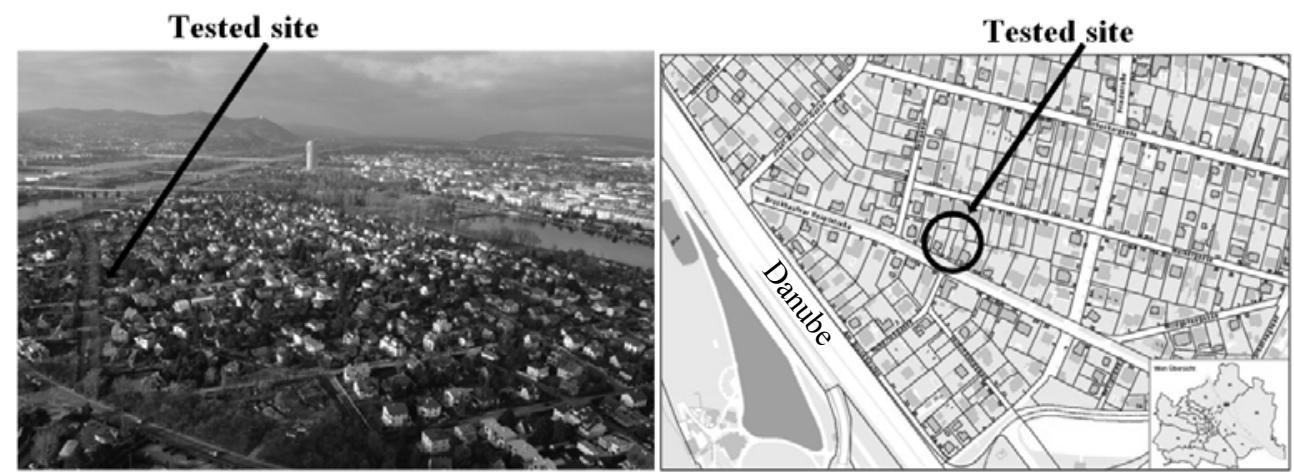

FIGURE 1. View of the Bruckhaufen housing estate and a spatial development plan of the area (source: Chagià José - Vienna, commons.wikimedia.org; Stadt Wien - ViennaGIS) 


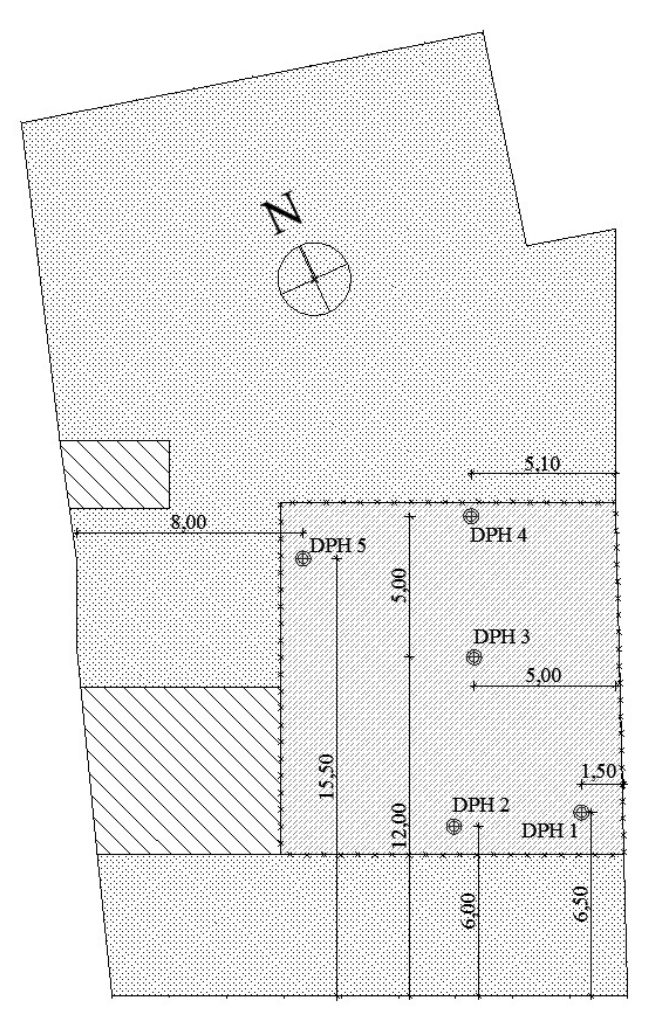

21.,Bruckhaufner Haupstraße 13

FIGURE 2. Location of the DPH control tests

ship between the density index $\left(I_{D}\right)$ and the number of hammer blows $\left(N_{k}\right)$ required to accomplish probe tip penetration to the depth of $k=10$ or $30 \mathrm{~cm}$. In the case when the probe penetrates below the groundwater level, correction indexes are applied.

In the test conducted on the study object, dynamic probing was applied, in which this relationship is calculated according to the following general formula (Witt 2008, Zilch et al. 2012):

$I_{D}=a_{1}+a_{2} \cdot \log N_{k}$

where:

$a_{1}, a_{2}$-emprical indexes.

Based on Eurocode EN 1997-2:2006, for conditions most approximate to the study objects, i.e. unsorted sands with uniformity coefficient at $C_{U} \leq 3$, above the groundwater level, when applying a heavy dynamic penetrometer (DPH) the following formula is used to determine the density index $\left(I_{D}\right)$ :

$I_{D}=0.10+0.435 \cdot \log N_{10 H}$

This relationship is presented in Figure 4.

\section{TEST RESULTS}

Tests with application of a heavy dynamic penetrometer DPH-50 were conducted in spring (April) using a device with a cone tip characterized by point angle of $\varphi=90^{\circ}$ and nominal base area of $A=$ $=15 \mathrm{~cm}^{2}$. The diameter of the tip base was $D=43.7 \mathrm{~mm}$, and the cone height was $L=21.9 \mathrm{~mm}$. Rods with a mass of $m=6 \mathrm{~kg} / \mathrm{m}$ had an external diameter of $O D=32 \mathrm{~mm}$. A hammer with a mass of $m=50 \mathrm{~kg}$ fell freely from the height of $h=500 \mathrm{~mm}$. The blow frequency was about 30 per $1 \mathrm{~min}$. The number of hammer blows $\left(N_{10}\right)$ per $10 \mathrm{~cm}$ of probe penetration was counted.

The influence of soil friction on the rods was omitted (the rods were not revolved after $1 \mathrm{~m}$ of probe penetration), because the test was conducted in non-cohesive made soils without intercalations of cohesive soils. The application of heavy dynamic penetrometer to the depth of $20 \mathrm{~m}$ below surface level does not require accounting for soil friction against the rods (Borowczyk and Frankowski 1985, Giżyński 1998, Sulewska 2005).

Additionally, according to the instruction of soil research, soil friction against the rods is not taken into account 


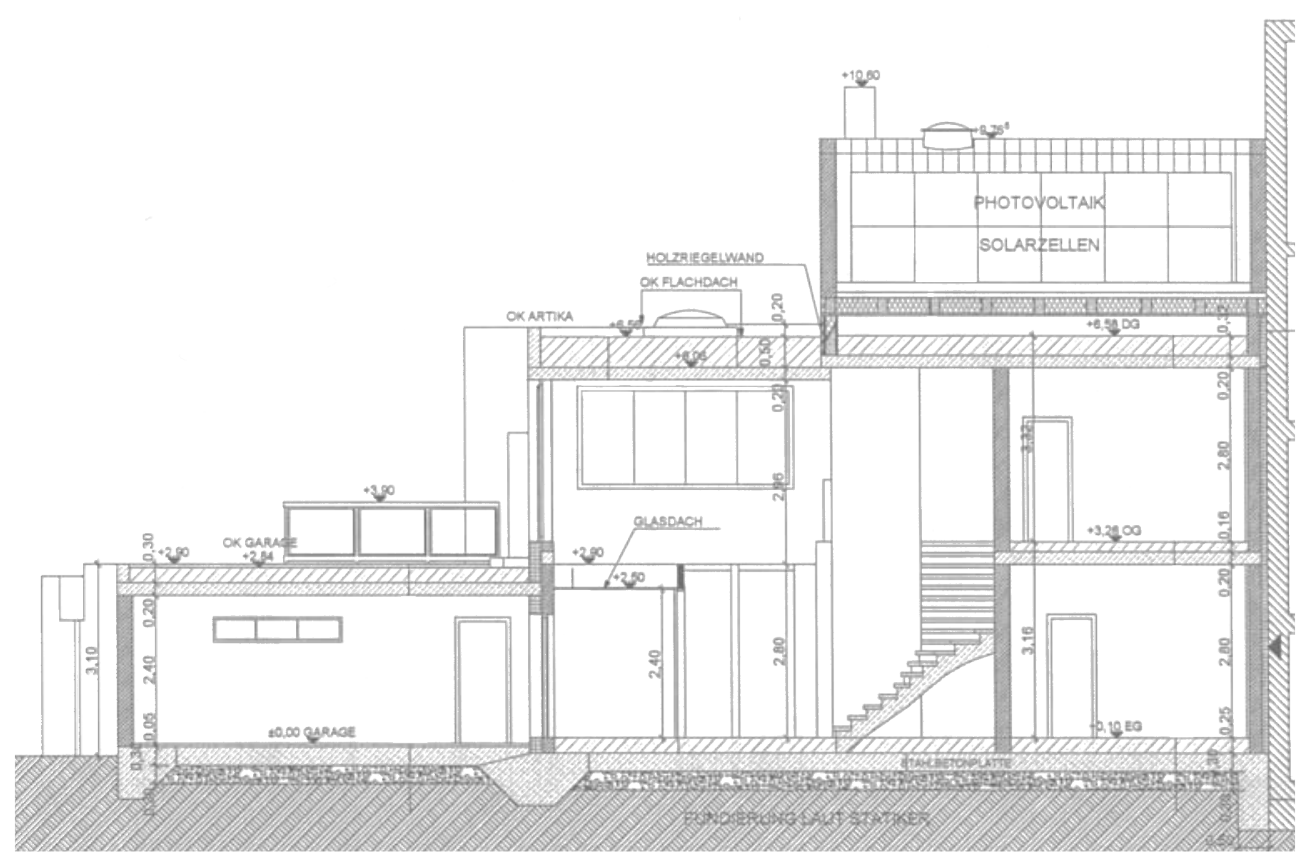

FIGURE 3. Longitudinal cross-section through the studied object (Schiener 2009)

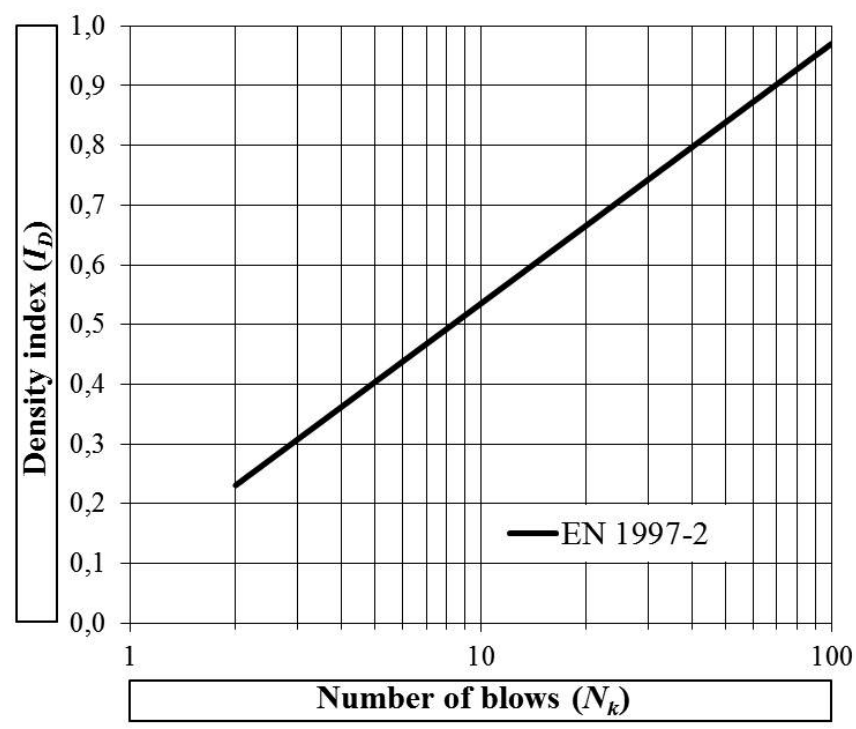

FIGURE 4. Correlation between the density index $\left(I_{D}\right)$ and the number of blows $\left(N_{10}\right)$ for the DPH probe 


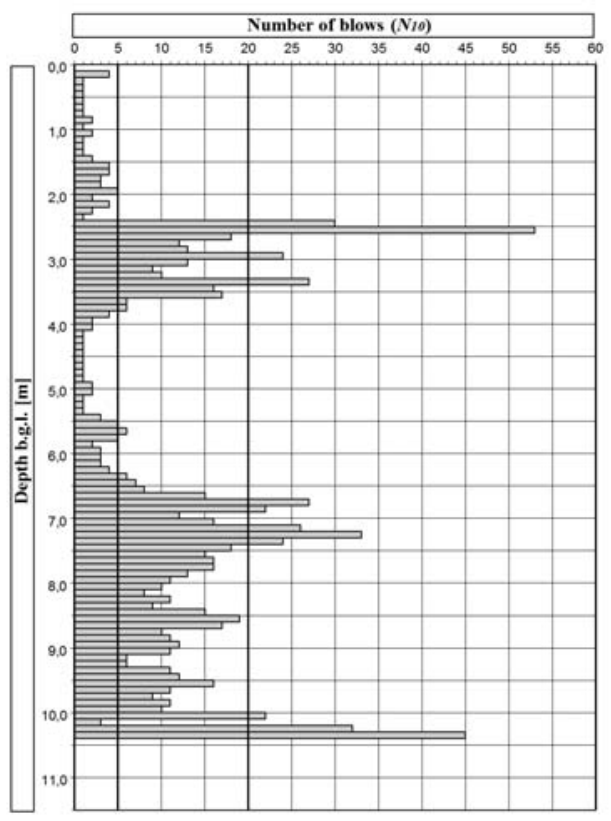

FIGURE 5. Results of tests $\left(N_{10}\right)$, DPH 1

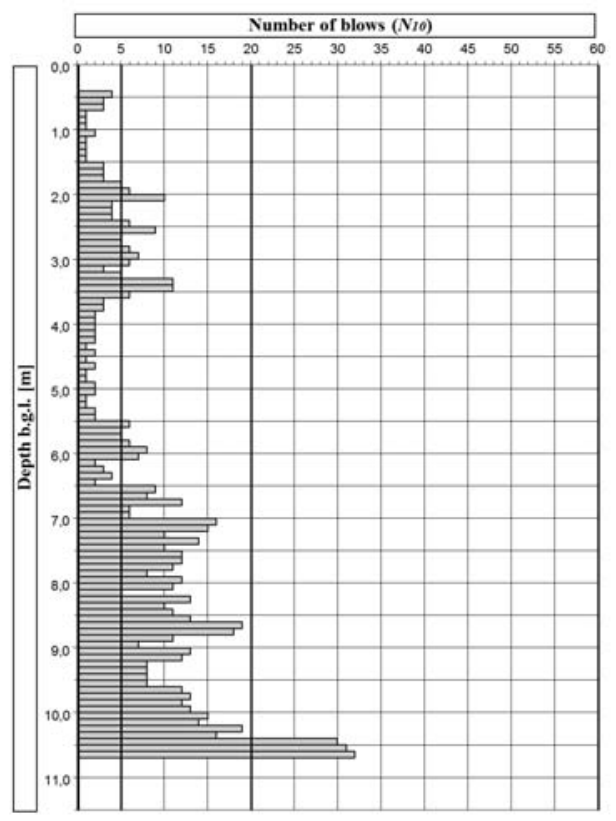

FIGURE 7. Results of tests $\left(N_{10}\right)$, DPH 3

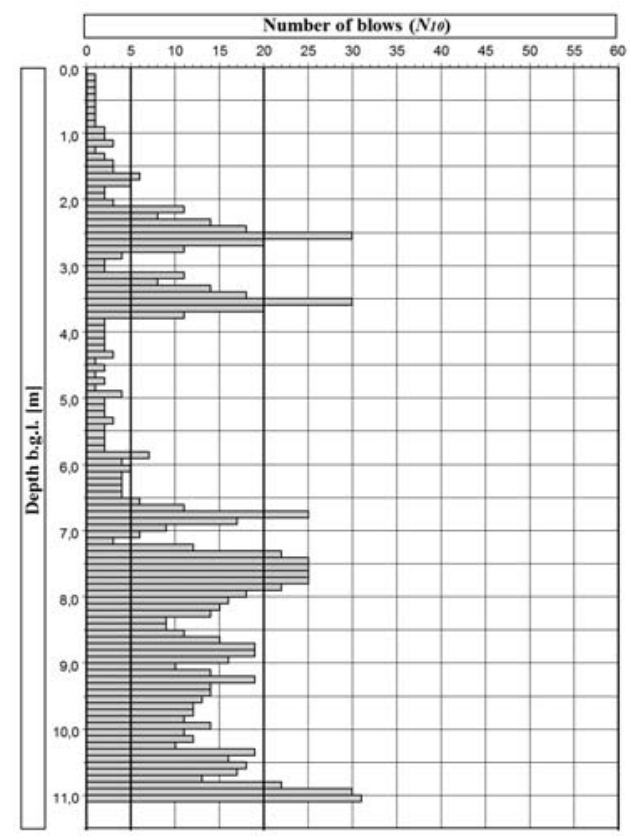

FIGURE 6. Results of tests $\left(N_{10}\right)$, DPH 2

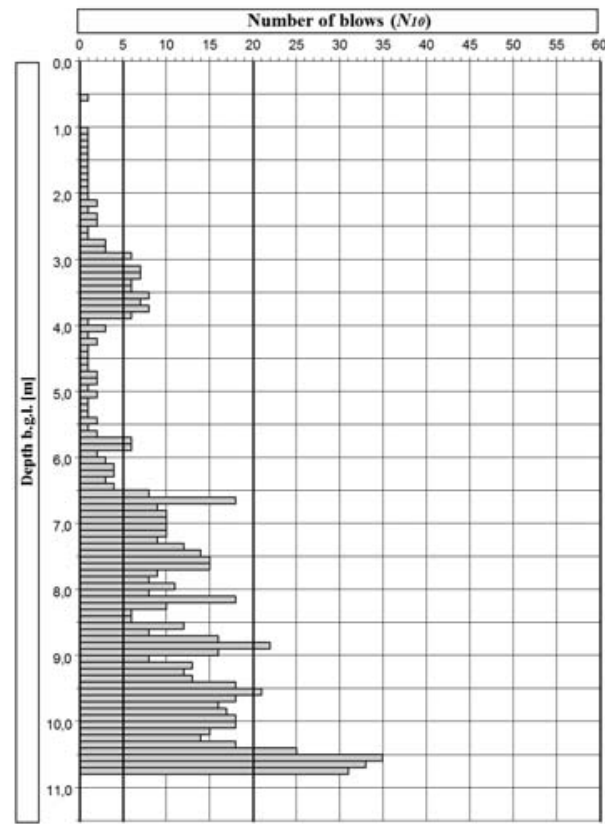

FIGURE 8. Results of tests $\left(N_{10}\right)$, DPH 4 


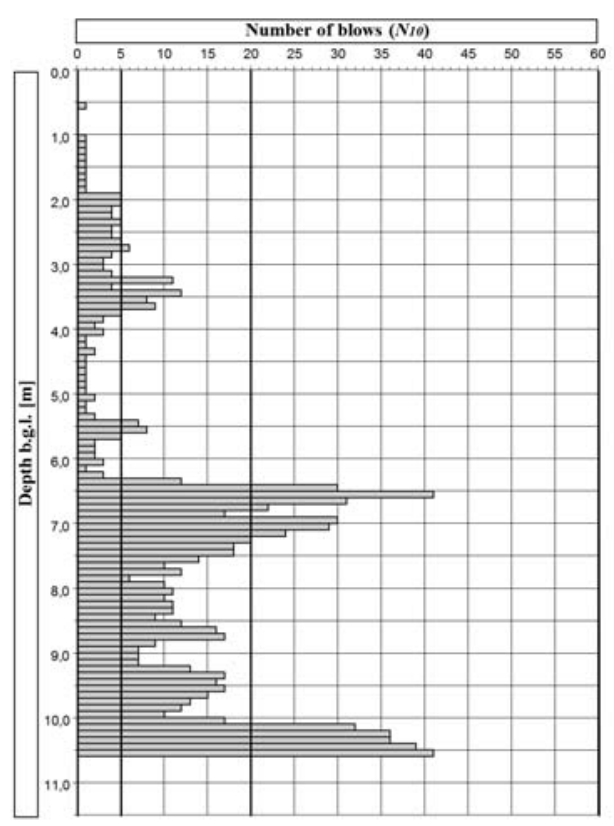

FIGURE 9. Results of tests $\left(N_{10}\right)$, DPH 5

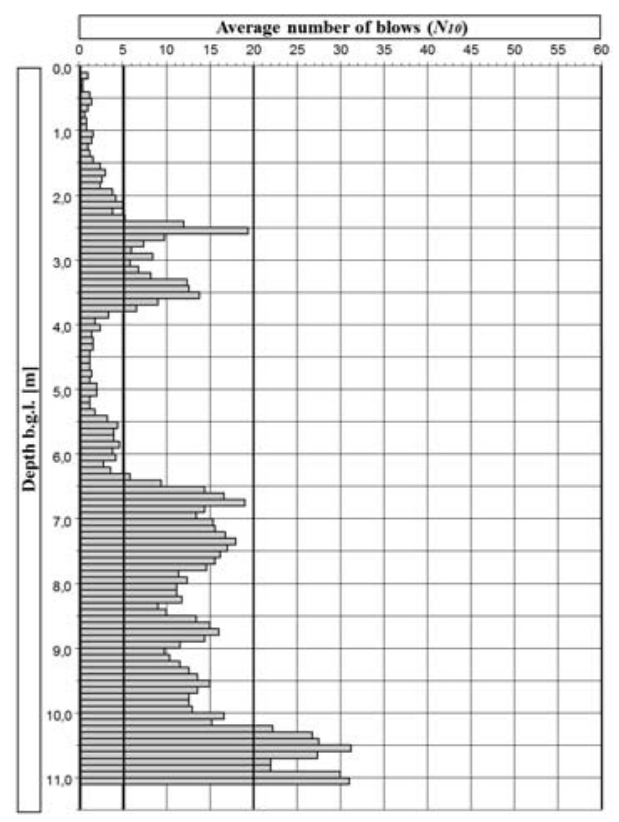

FIGURE 10. Average results $\left(\overline{N_{10}}\right)$, DPH when the ratio of the tip diameter to the rod diameter is above 1.3 (Kłosiński et al. 1998).

Tests in the object were conducted to the assumed thickness of $11 \mathrm{~m}$ below surface level or till obtaining a blow number $\left(N_{10}\right)$ of 30 or larger at 2-3 subsequent stretches of probe penetration.

Figures 5-9 (Fig. 10 - average results) present the number of blows $\left(N_{10}\right)$ per each $10 \mathrm{~cm}$ of probe tip penetration obtained in the network nodes, marked as DPH 1-DPH 5 (Fig. 2). The tests were conducted using Austrian norm ÖNORM B 4419:2006 and the German norm DIN 4094-2:2003, which are consistent with European norm EN 1997-2:2006 known as Eurocode 7 (Bagieńska 2009).

\section{INTERPRETATION OF THE OBTAINED RESULTS}

Determination of the density state of non-cohesive soils from the relationship between the density index $\left(I_{D}\right)$ and the number of hammer blows $\left(N_{k}\right)$ can be considered a safe measure, because it is based on the averaged results obtained by numerous authors from different research centres that apply dynamic probing in practice (Borowczyk and Frankowski 1979, 1985, Tarnawski, 2010, Boutet et al. 2011).

Standardization of the measurement results obtained with application of dynamic probing allows direct comparison of the density index $\left(I_{D}\right)$ for the same types of non-cohesive soils occurring in different areas (Tarnawski 2010). Table 1 shows the ranges of the density index $\left(I_{D}\right)$ for different soil types in the 
TABLE 1 . Correlation between the soil state and the density index $\left(I_{D}\right)$

\begin{tabular}{|l|c|c|c|}
\hline Soil type & Grading & \multicolumn{2}{|c|}{$I_{D}$ range } \\
\hline \multirow{3}{*}{$\begin{array}{l}\text { Sand with small admixture of fine } \\
\text { fraction, sand, gravel sand }\end{array}$} & \multirow{3}{*}{ unsorted $\left(C_{U}<6\right)$} & $0.15-0.35$ & loose \\
\cline { 3 - 4 } & & $0.35-0.65$ & medium density \\
\cline { 3 - 4 } & & $>0.65$ & density \\
\hline
\end{tabular}

study area according to the compulsory norm EN 1997-2:2006.

Correct selection of the devices for the planned investigations and assurance of correct activities and result estimation required initial recognition of the substrate. Analysis of available data and field observations allowed locating the network nodes and recognize the variability of soil and groundwater conditions in the substrate. Groundwater did not occur in the study area, therefore there was no need to introduce correction indexes for the registered number of blows.
The conducted tests supplied data on the soil types occurring in the substrate. Based on curves of grain size distribution (Fig. 11), prepared for five nodes, ISO triangles determined the presence of gravel sand in the study area (grSa according to norm ISO 14688-1:2002). The uniformity coefficient for this soil was $C_{U}=3.2$.

Deformations of the foundation mat are presented in Figure 12. The values of the deformations $(u)$ attain values from 1.05 to $9.28 \mathrm{~mm}$.

Figures 13-17 present the value of the density index $\left(I_{D}\right)$ calculated from

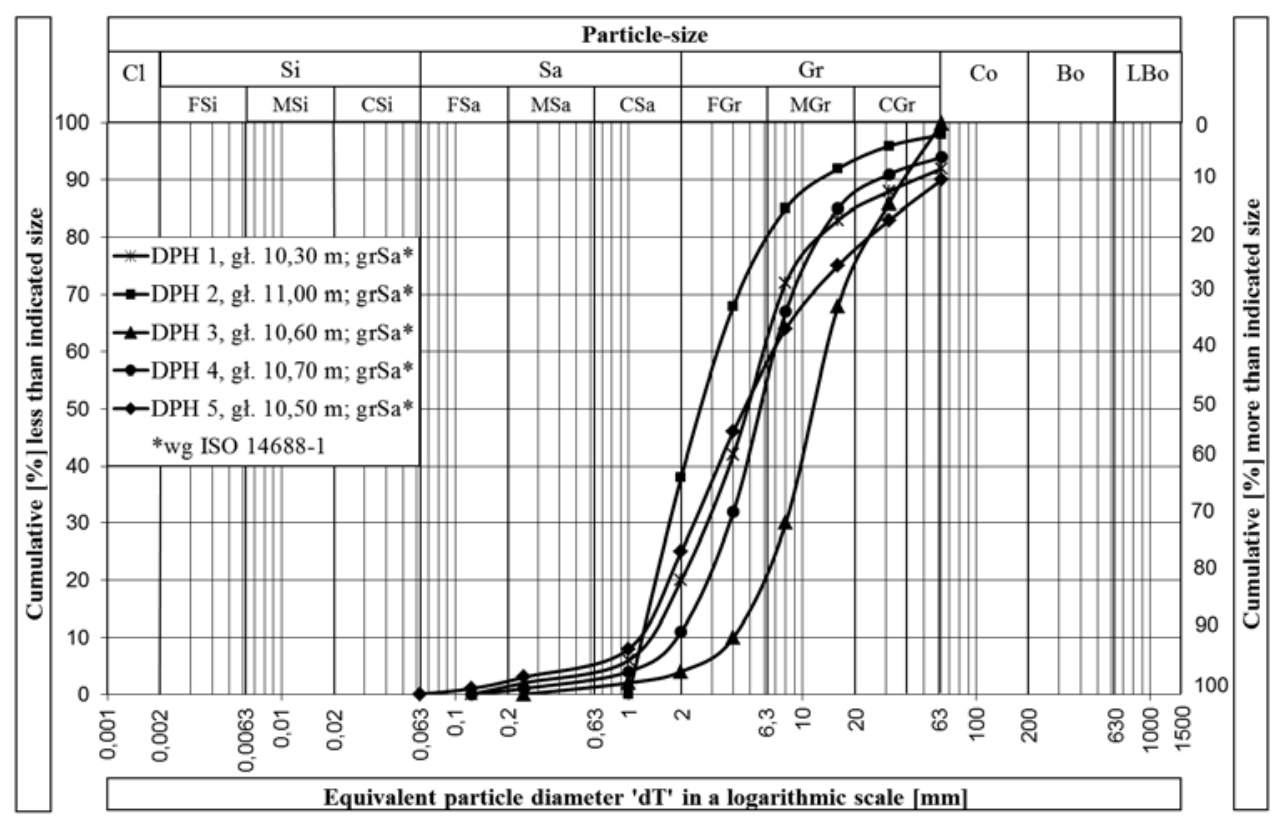

FIGURE 11. Curves of grain size distribution for soils in the study site 


\section{Legend:}

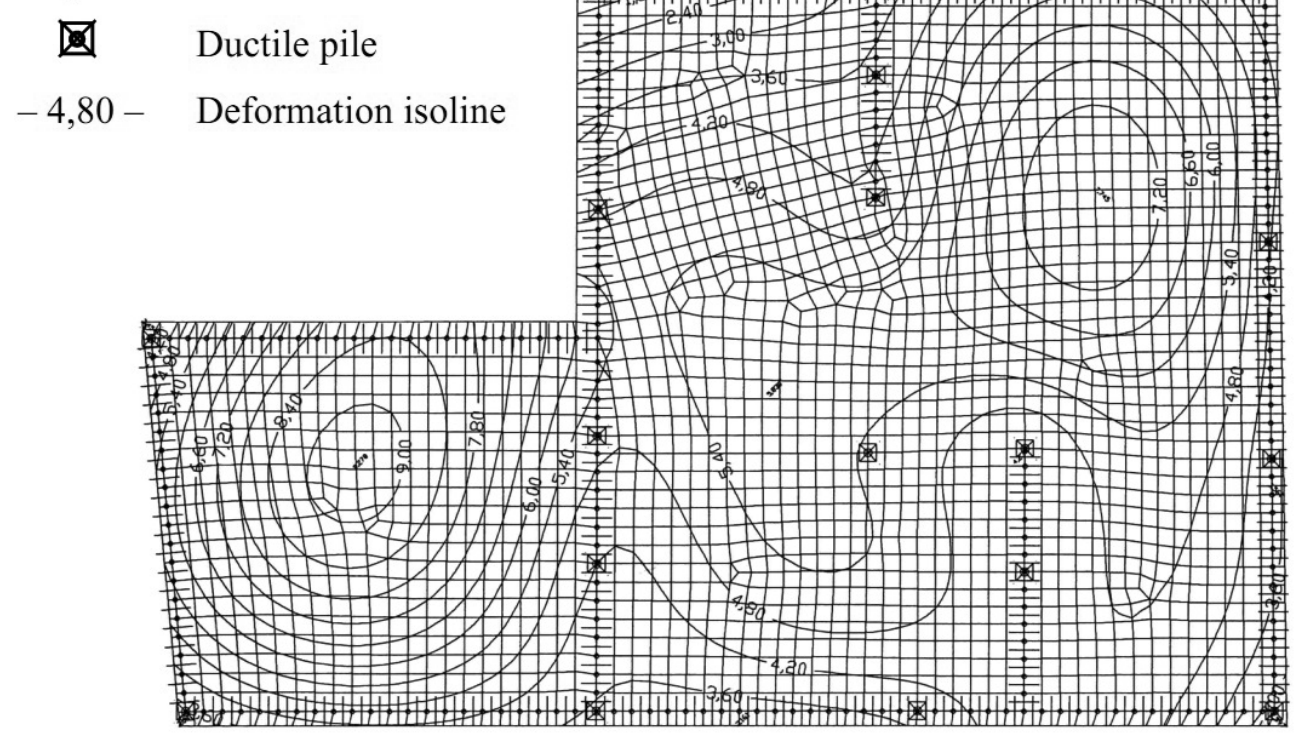

FIGURE 12. Deformations of the foundation slab (Hejkrlik 2009)

formula (2) depending on the test depth in measurement nodes in the study area.

Analysis of particular diagrams shows that the soil density state below the critical depth $t_{c}=1.0 \mathrm{~m}$ to about $1.8 \mathrm{~m}$ below the surface is loose and then rises to medium dense to the depth of about $3.8 \mathrm{~m}$. Between 3.8 and $6.2 \mathrm{~m}$ of depth, the soil is in a loose density state. In all diagrams, the medium density state of the soil in the study area occurs from the depth of about $6.2 \mathrm{~m}$ below the surface and increases to a dense state at the depth of about $10.2 \mathrm{~m}$. Due to determination of dense soil at depths below $10 \mathrm{~m}$, the building foundation was designed in form of a foundation mat with a thickness of $d=20 \mathrm{~cm}$, settled on 18 prefabricated ductile piles, each with a diameter of $\varnothing=118 \mathrm{~mm}$ and length of $l=10 \mathrm{~m}$.

The average values of the density in$\operatorname{dex}\left(I_{D}\right)$ in the study area are presented in Figure 18. The density index for the abundance of $n=101$ varies in the range between 0.10 and 0.75 , while their average value is $\overline{I_{D}}=0.46$. The standard deviation for the population $\bar{\sigma}=0.1847$, population variance $\sigma^{2}=0.0341$ and skewness $S K E=-0.4648$ at a standard error $S E=0.0184$ were determined with a probability of $p=0.95$.

\section{CONCLUSIONS}

Dynamic probing may be used to determine the density state of non-cohesive and anthropogenic soils during designing building foundations on a substrate built of anthropogenic made soils.

Dynamic probing allows verifying the goals of project requirements on the relevant densification of soils integrated in the substrate and indicating potential needs for its densification or accepting alternative solutions, as e.g. stabilization of the soil substrate or indirect foundation. 


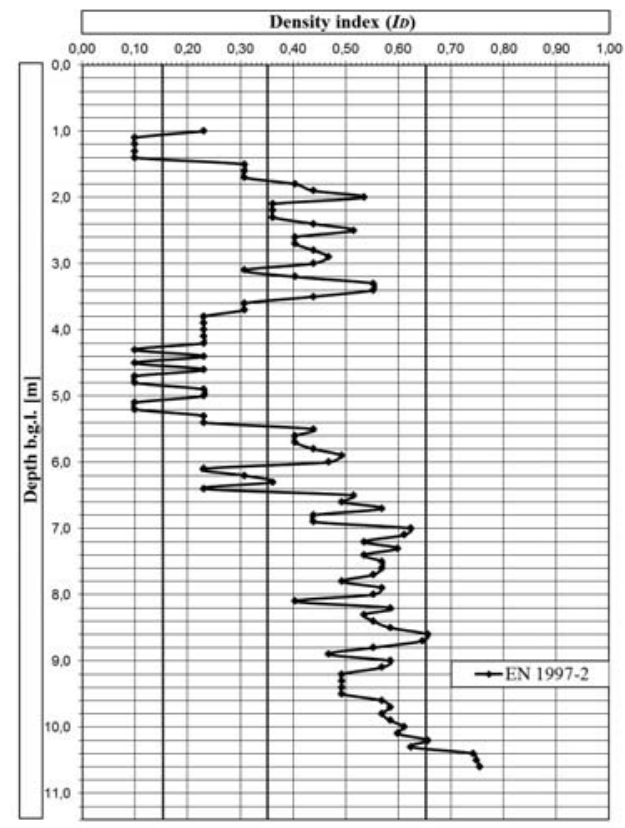

FIGURE 13 . Density index $\left(I_{D}\right)$, DPH 1

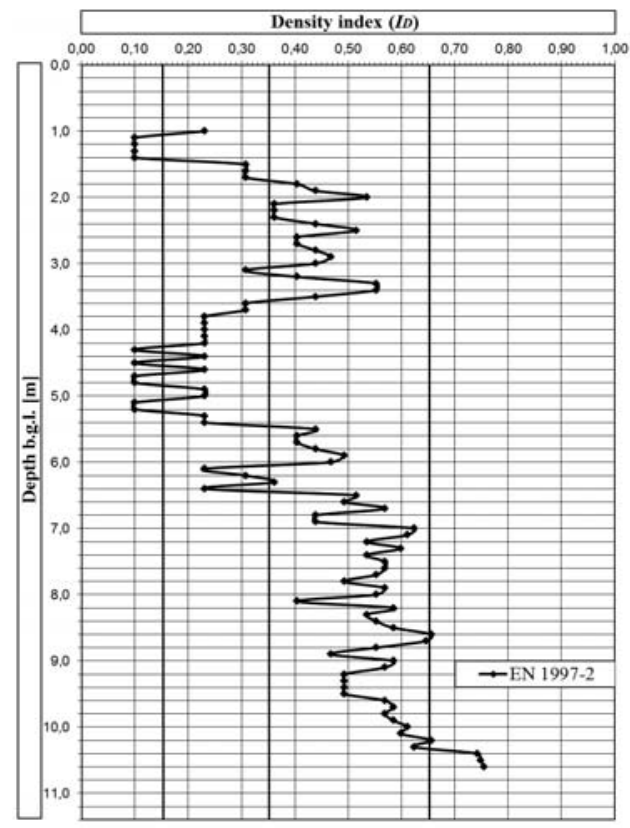

FIGURE 15 . Density index $\left(I_{D}\right)$, DPH 3

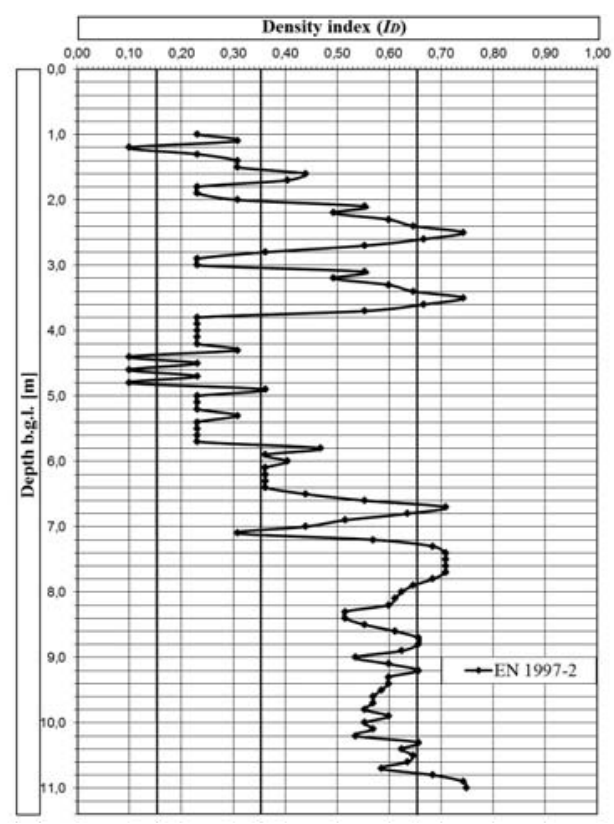

FIGURE 14 . Density index $\left(I_{D}\right)$, DPH 2

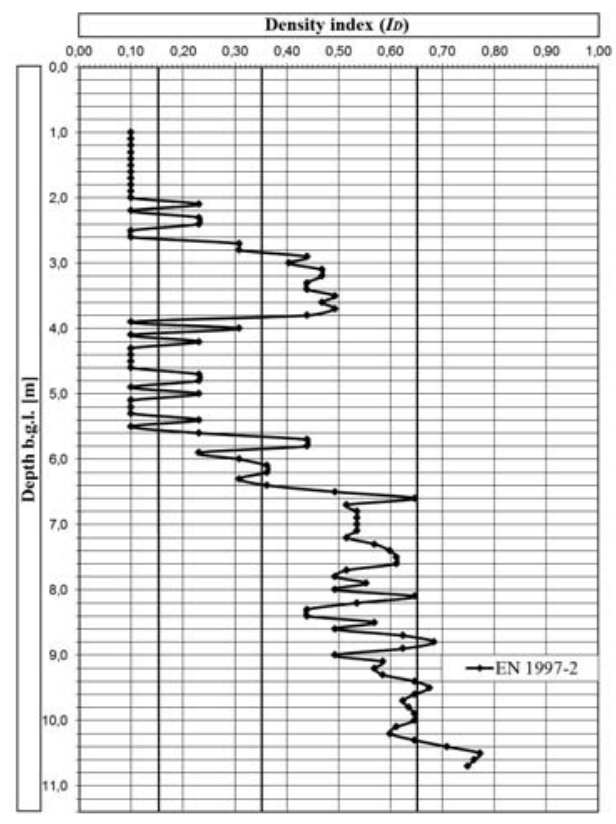

FIGURE 16. Density index $\left(I_{D}\right)$, DPH 4 


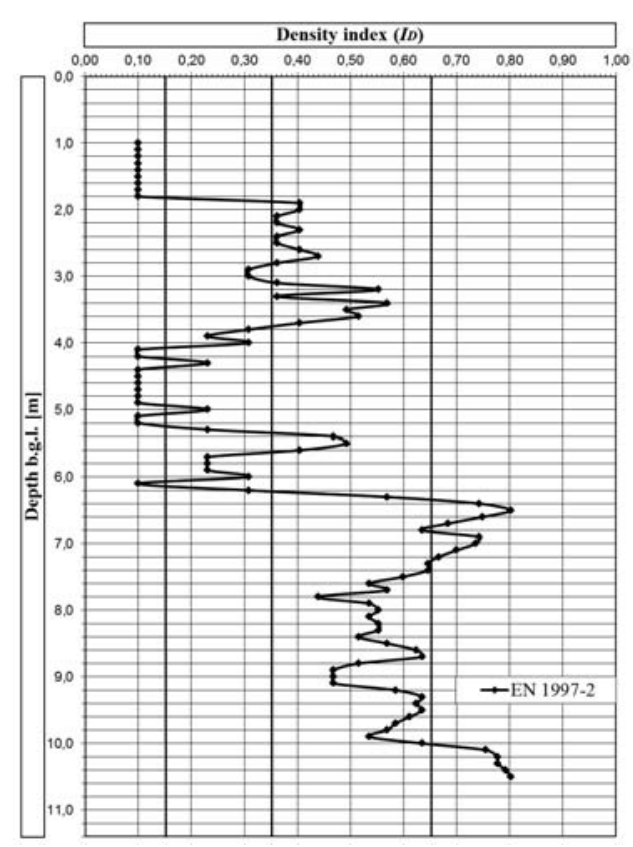

FIGURE 17. Density index $\left(I_{D}\right)$, DPH 5

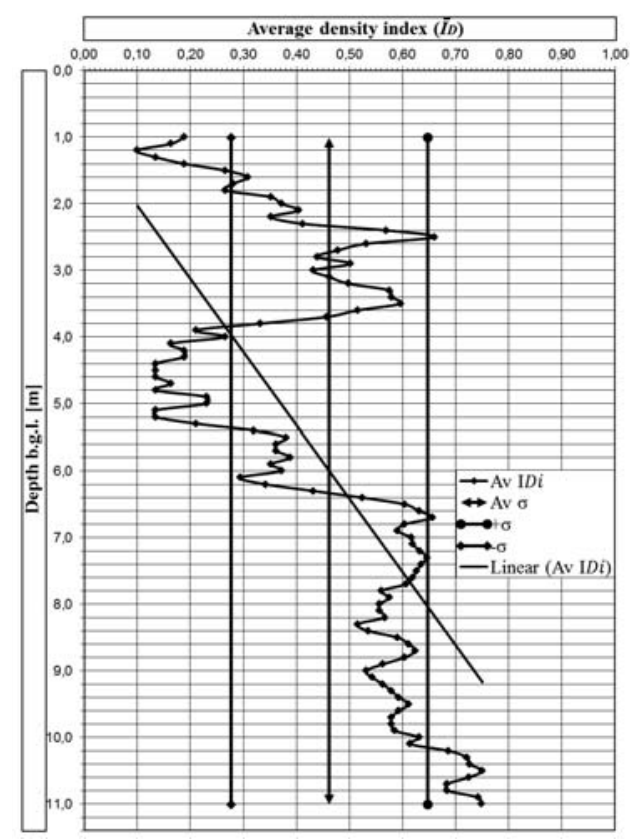

FIGURE 18 . Summary statistics $\left(\overline{I_{D}}\right), \mathrm{DPH}$
Application of a heavy dynamic penetrometer for determining the density state of made soils in the described object has confirmed the usefulness of this method in studies of anthropogenic made soils and allowed the application of a safe method of founding the designed building.

\section{REFERENCES}

BAGIEŃSKA I. 2009: Rozpoznanie i badanie podłoża gruntowego metodami polowymi w ujęciu Eurokodu 7. Górnictwo $i$ Geoinżynieria 33(1), 39-46.

BOROWCZYK M., FRANKOWSKI Z. 1979: Możliwości oceny podłoża gruntowego na podstawie sondowań dynamicznych. Inżynieria i Budownictwo 12 , 442-444.

BOROWCZYK M., FRANKOWSKI Z. 1985: Porównanie wyników badań sondowań dynamicznych gruntu w Polsce i RFN. Inżynieria $i$ Budownictwo 12, 448-449.

BOUTET M., DORE G., BILODEAU J.-P., PIERRE P. 2011: Development of models for the interpretation of the dynamic cone penetrometer data. International Journal of Pavement Engineering 12(3), 201-214.

DIN 4094-2:2003-05. Baugrund. Felduntersuchungen Teil 2: Bohrlochrammsondierung. DIN. Beuth Verlag, Berlin.

EN 1997-2:2006-06. Eurocode 7 - Geotechnical design - Part 2: Ground investigation and testing. CEN, Brussels.

GIŻYŃSKI T. 1998: Metodyka cechowania sondy dynamicznej ciężkiej. Inżynieria Morska i Geotechnika 4, 186-193.

GLINICKA M.J. 2006: Badanie laboratoryjne zagęszczalności gruntów antropogenicznych. Zeszyty Naukowe Politechniki Białostockiej, Budownictwo 28(1), 89-98. 
HEJKRLIK G. 2009: Neubau eines Wohnhauses in der Bruckhaufner Hauptstr. 13, A-1210 Wien. Statische Vorbemessung, Wien, 70.

HERRICK J.E., JONES T.L. 2002: A dynamic cone penetrometer for measuring soil penetration resistance. Soil Science Society of America Journal 66(4), 1320-1324.

ISO 14688-1:2002-09. Geotechnical investigation and testing - Identification and classification of soil - Part 1: Identification and description. CEN, Brussels.

ISO 22476-2:2005-1. Geotechnical investigation and testing - Field testing - Part 2: Dynamic probing. CEN, Brussels.

KŁOSIŃSKI B., BAŻYŃSKI J., FRANKOWSKI Z., KACZYŃSKI R., WIERZBICKI S. 1998: Instrukcja Badań Podłoża Gruntowego Budowli Drogowych i Mostowych. Part 2. Appendix, Chapter 2: Metody badań, 2.2: Prace terenowe. Instytut Badawczy Dróg i Mostów, Warszawa, 8-37.

KODA E. 2011: Stateczność rekultywowanych składowisk odpadów i migracja zanieczyszczeń przy wykorzystaniu metody obserwacyjnej. Chapter 5. Bezpieczeństwo geotechniczne składowisk - stateczność i odkształcenia. Rozprawy Naukowe i Monografie. Wydawnictwo SGGW, Warszawa, 81-145.

KODA E. 2012: Anthropogenic waste products utilization for old landfills rehabilitation. Annals of Warsaw University of Life Sciences - SGGW, Land Reclamation 44(1), 75-88.

LAMPERT C., MORF L., OBERNOSTERER R., RECHBERGER H., REINER I., BRUNNER P.H. 1996: Der anthropogene Stoffhaushalt der Stadt Wien. Technische Universität Wien. Institut für Wassergüte und Abfallwirtschaft. COMPRESS Verlagsgesellschaft, Wien.

LICKA L., KRIPPNER U. 2011: 50 Jahre Donaupark: stadtplanerische Vision i Dimension. Kapitel 2. Geschichte des Säulenhaufens 2.3. Mülldeponie Bruckhaufen. Universität für Bodenkultur. Institut für Landschaftsarchitektur, MA 18 Stadtentwicklung und Stadtplanung, Wien, 9-12.
ÖNORM B 4419:2006-12. Geotechnik - Besondere Rammsondierverfahren. ASI, Wien.

PASIK T., CHALECKI M., KODA E. 2015: Analysis of embedded retaining wall using the subgrade reaction method. Studia Geotechnica et Mechanica 37(1), 59-73.

PATAKIEWICZ M.A., ZABIELSKA-ADAMSKA K. 2013: Coefficient of curvature and compaction parameters for non-cohesive soils with bimodal grain size distribution. Acta Scientiarum Polonorum, Architectura 12(3), 111-123.

PISARCZYK S. 2012: Gruntoznawstwo inżynierskie. Chapter 15. Badania terenowe gruntów. I Edn. Wydawnictwo Naukowe PWN, Warszawa, 240-278.

SCHIENER H. 2009: Neubau eines Wohnhauses in der Bruckhaufner Hauptstr. 13, A-1210 Wien. Einreichplan, Wien.

SULEWSKA M. 2005: Interpretacja wyników badania gruntów lekką sondą dynamiczną DPL. Inżynieria i Budownictwo 3, 145-146.

TARNAWSKI M. 2010: O potrzebie weryfikacji interpretacji wyników sondowań dynamicznych w gruntach niespoistych. Inżynieria Morska i Geotechnika 3, 441-443.

WITT K.J. 2008: Grundbau-Taschenbuch. Teil 1: Geotechnische Grundlagen. Kapitel 1.2: Baugrunduntersuchungen im Feld. 7. Aufl. Ernst \& Sohn, Berlin, 43-121.

ZADROGA B. 2007: Wykorzystanie wyników sondowań dynamicznych gruntów niespoistych $\mathrm{w}$ projektowaniu geotechnicznym. Prace Naukowe Politechniki Warszawskiej, Inżynieria Środowiska 54, 215-222.

ZILCH K., DIEDERICHS C.J., KATZENBACH R., BECKMANN K.J. 2012: Handbuch für Bauingenieure. Technik, Organisation und Wirtschaftlichkeit. Kapitel 4: Geotechnik 4.3: Grundbau, Baugruben und Gründungen. 2. Aufl. aktual. Springer-Verlag, Heidelberg, 1568-1639. 
Streszczenie: Ocena stanu zagęszczenia antropogenicznych gruntów nasypowych sondq dynamicznq ciężkq (DPH). Wytrzymałość gruntów naturalnych niespoistych $\mathrm{i}$ antropogenicznych można w warunkach polowych określić za pomocą sondowania dynamicznego. Metoda ta polega na mierzeniu oporu, jaki badany grunt stawia końcówce sondy podczas jej zagłębiania. Najczęściej stosuje się sondy o końcówkach cylindrycznej, stożkowej i rzadziej, krzyżakowej. Do pograżania w podłoże gruntowe końcówki sondy ze stałą energią uderzenia stosuje się młot o danej masie spadający swobodnie $\mathrm{z}$ wysokości wymaganej w badaniu. W wyniku przeprowadzonych prób otrzymuje się liczbę uderzeń przypadających na jednostkę zagłębienia sondy $\left(N_{k}\right)$, gdzie $k=10,15(20)$ lub $30 \mathrm{~cm}$. W artykule przedstawiono wyniki badań sondą dynamiczną ciężką DPH, o masie młota
$50 \mathrm{~kg}$ i głębokości penetracji do $30 \mathrm{~m}$, przeprowadzone $\mathrm{w}$ antropogenicznych gruntach nasypowych celem określenia wytrzymałości podłoża gruntowego pod fundament projektowanego budynku.

Stowa kluczowe: sondowanie dynamiczne, sonda ciężka, stopień zagęszczenia, antropogeniczne grunty nasypowe

\section{Author's address:}

Wojciech Czaczkowski

AUGENTA Bau Ges.m.b.H.

Hainburger Straße 21/2, 1030 Wien

Austria

e-mail: wojciech_czaczkowski@yahoo.com 